RANCHERO REVOLT 
The Texas Pan American Series 


\title{
RANCHERO REVOLT The Mexican Revolution in Guerrero
}

\author{
by Ian Jacobs
}

$\checkmark$ University of Texas Press, Austin 
For Jan and for my parents

Copyright $(1) 1982$ by the University of Texas Press

All rights reserved

Printed in the United States of America

First Edition, 1982

Requests for permission to reproduce material from this work should be sent to Permissions, University of Texas Press, Box 7819 , Austin, Texas 78712.

The Texas Pan American Series is published with the assistance of a revolving publication fund established by the Pan American Sulphur Company.

Library of Congress Cataloging in Publication Data

Jacobs, Ian, 1952-

Ranchero revolt.

(The Texas Pan American series)

Bibliography: $p$.

Includes index.

1. Guerrero (Mexico: State)-History. 2. Land tenure-Mexico-Guerrero

(State)-History. 3. Peasantry-Mexico-Guerrero (State)-History. I. Title. II. Series.

F1 286.133 1982 $972^{\prime} .7308 \quad 82-8601$

ISBN: 978-0-292-74119-5 AACR2 